The lessons which we have learned from visiting Russian metallurgical institutes may be summarized briefly as follows: The general program is tailored to the needs of Russian industry. Each student is well trained for a specific kind of job in a specific industry. The product seems to be satisfactory to industry, and it appears that a Diploma in metallurgical engineering is a sine qua non for industrial advancement. The degree of specialization and the extent of training go far beyond the usual American practice. To a considerable degree, educational breadth is sacrificed to specialized training. This is a sacrifice which cannot be recommended to American schools.

In numbers, the Russians are far ahead of us in the training of metallurgists. More emphasis should be given to metallurgy in American schools, and renewed efforts must be made to increase the enrollment of superior students. Laboratory equipment for instruction in metallurgy in the Russian schools is superior to that in our own. This is true in respect to the quantity of good equipment available and the diversity and advanced nature of the laboratory experiments for which equipment is provided.

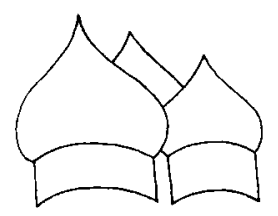

\title{
Non-Ferrous Metallurgical Training
}

\author{
David Swan, Director of Research, the Linde Co., Div. of Union Carbide \\ Corp., had some interesting comments on the Kalinin Institute for Non- \\ Ferrous Metals in Moscow....
}

Non-ferrous teaching institutes are located in Moscow, Leningrad, Alma-Ata, Irkutsk, and Sverdlovsk, but the Kalinin Institute in Moscow is the largest in the USSR.

The primary purpose of the Kalinin Institute, which was founded in 1930 , is to teach engineers for jobs in the non-ferrous metallurgical industry. There are five departments comprising: geology, mining, metallurgical, technological, and economic engineering. The department of metallurgy has two specialties: enrichment of ores and metallurgy of non-ferrous metals. The technological department has three specialties: metallography and heat treatment, treatment of metals under pressure, and smelting and reduction.

Approximately 2500 students attend the Institute for a five-year course. In addition, there are about 200 graduate students. The teaching staff consists of 300 of whom 40 are professors with doctor's degrees and more than 100 teaching assistants with Candidat degrees.

Approximately five subjects are given during each academic year, which is divided into two terms plus a practical work period. For the first two years, students attend school full time, but after the second year they spend 7 to 8 weeks per year on practical production problems in plants and factories. About one third of the total study time is in the field of general sciences, such as mathematics, physics, and chemistry, while the remainder is in physical sciences on subjects pertinent to the specialty chosen. These studies begin in the second or third year, depending upon the specialty. Humanities comprise courses in dialetical materialism, historical materialism, political economy, and a language, either English or German. No literature or history are given.

The choice of specialty is supposedly voluntary. The specialties given in the department of metallurgy include: heavy metals, light metals, rare metals, and noble metals. In the technological department specialties consist of metallography, heat treatment, and smelting. The metallography specialty is further broken down into subdivisions comprising powder metallurgy, corrosion, and electro- chemistry. The student chooses his faculty (department) immediately upon entering the Institute.

\section{Examinations}

Formal examinations are given twice a year, in January and June. If the course runs for a full academic year, only one examination is given, in June. All examinations are oral. They are marked on a scale of five for excellent, going down to two for failure. For the examination the student is handed a ticket on which is printed three questions which he must answer. Informal examinations are given during the course of the semester, and questions of the same type are included in these examinations. The oral examinations are given individually and last for approximately $30 \mathrm{~min}$. Written tests are also given during the course of the year.

\section{The stipend}

Whether or not a stipend is granted is determined by need and the record of the student. After the first year it is based entirely upon the school record. At the present time 85 pct of the students receive stipends which may be rescinded for either poor dis cipline or poor marks. The size of the stipend is 300 rubles per month for the first year and increases progressively to 500 rubles for the fifth year students. Rooms are furnished by the Institute at approximately 15 rubles per month. Board must be paid by the student, who makes his own arrangements.

\section{Job selection}

The school record is very important in the selection of a job upon graduation. A list of plants requiring different types of specialties is posted at the school, and a committee composed of the director of the Institute, representatives of the Institute, and representatives of industry assign students to the various job opportunities. In many cases, after the students and jobs are matched by this committee, the plant manager may interview the student and may rescind an offer. The student may also turn down a specific job offer. In some cases the number of graduates are greater than the jobs available, and then the student must find his own job. 